\title{
Polypyrrole/copper hexacyanoferrate hybrid as redox mediator for glucose biosensors
}

\author{
Pablo A. Fiorito ${ }^{a}$, Christopher M.A. Brett ${ }^{b}$, \\ Susana I. Córdoba de Torresi ${ }^{\text {a,* }}$ \\ ${ }^{a}$ Instituto de Química, Universidade de São Paulo, C.P. 26077, 05513-970 São Paulo (SP), Brazil \\ ${ }^{\mathrm{b}}$ Departamento de Química, Universidade de Coimbra, 3004-535 Coimbra, Portugal
}

Received 22 August 2005; received in revised form 30 September 2005; accepted 30 September 2005

Available online 14 November 2005

\begin{abstract}
A copper containing Prussian Blue analogue was incorporated into a conducting polypyrrole film. The modified electrode was synthesized through an electrochemical two-step methodology leading to very stable and homogeneous hybrid films. These electrodes were proved to show excellent catalytic properties towards $\mathrm{H}_{2} \mathrm{O}_{2}$ detection, with a performance higher than those observed for Prussian Blue and other analogues. Electrochemical impedance spectroscopy experiments demonstrated that the excellent performance of these hybrid films is strongly related to the electronic conductivity of the polymeric matrix that is wiring the copper hexacyanoferrate sites. A glucose biosensor was built-up by the immobilization of glucose oxidase; the sensitivity obtained being higher than other biosensors reported in the literature even in $\mathrm{Na}^{+}$containing electrolytes.
\end{abstract}

(C) 2005 Elsevier B.V. All rights reserved.

Keywords: Prussian Blue analogues; Polypyrrole; Hybrid materials; Glucose biosensors

\section{Introduction}

In recent years the construction and application of modified electrodes has received much attention with a view to the enhancement of sensitivity and selectivity of electroanalytical techniques. The use of metal hexacyanoferrates in modified electrodes has been extensively studied [1]. These kinds of materials are becoming widely used as redox mediators in biosensors based on oxidase enzymes as the biological recognition element. These enzymes oxidize their specific substrates in the presence of molecular oxygen leading to the formation of hydrogen peroxide as side product $[2,3]$. Due to the fact that these materials proved to be excellent catalysts for $\mathrm{H}_{2} \mathrm{O}_{2}$ reduction at low potentials, minimizing the interference caused by reductant species, hexacyanoferrates have been widely studied. The possibility of selective detection mediated by Prussian Blue was first demonstrated by Karyakin et al. [4].

\footnotetext{
* Corresponding author.

E-mail address: storresi@iq.usp.br (S.I. Córdoba de Torresi).
}

Besides Prussian Blue, other metal hexacyanoferrate used as mediators in oxidase based biosensors are copper hexacyanoferrate $(\mathrm{CuHCNFe})[5-7]$, cobalt hexacyanoferrate $(\mathrm{CoHCNFe})$ [8-11] and nickel hexacyanoferrates (NiHCNFe) [12-14].

Among the analogues of Prussian Blue, copper hexacyanoferrate shows a well-defined, reversible and reproducible electrochemical response in supporting electrolytes containing not only potassium but also other alkali metal cations such as lithium, sodium, rubidium or cesium [15-18], contrary to Prussian Blue that only shows good electroactivity in electrolytes containing $\mathrm{K}^{+}$.

In this work, $\mathrm{CuHCNFe}$ is incorporated into the structure of a polypyrrole network. In previous work [19], we reported the synthesis of an inorganic/organic hybrid, combining polypyrrole and nickel hexacyanoferrate, obtaining a material with enhanced electrocatalytic and mechanical properties compared to nickel hexacyanoferrate by itself. In that case, the composite was formed by cyclic voltammetry in solutions containing nickel(II), hexacyanoferrate(III) and pyrrole. In this case, the methodology was changed, forming a film of hexacyanoferrate(III)-doped polypyrrole in a first step, followed by a second step where the 
insertion of $\mathrm{Cu}^{2+}$ was performed with the concomitant formation of $\mathrm{CuHCNFe}$ inside the conducting polymer matrix.

\section{Experimental}

\subsection{Reagents}

Analytical grade $\mathrm{CuCl}_{2} \cdot 2 \mathrm{H}_{2} \mathrm{O}, \mathrm{K}_{3} \mathrm{Fe}(\mathrm{CN})_{6}, \mathrm{KCl}$ and $\mathrm{NaCl}$ were purchased from Merck. All solutions were prepared with Milli-Q nanopure water (resistivity $\geq 18 \mathrm{M} \Omega \mathrm{cm}$ ). Pyrrole (Merck) was distilled prior to use. Experiments were carried out at room temperature $\left(24 \pm 1{ }^{\circ} \mathrm{C}\right)$.

\subsection{Instrumentation}

Cyclic voltammetry (CV) and chonoamperometry (CA) experiments were performed with a $\mu$-Autolab Type II potentiostat/galvanostat (EcoChemie, The Netherlands) driven by GPES 4.9 software. All potentials are referred to a saturated calomel electrode (SCE), while a platinum foil was employed as the auxiliary electrode. As working electrode, a glassy carbon (GC) electrode ( $3 \mathrm{~mm}$ diameter) was used.

Electrochemical impedance measurements were carried out in the same electrochemical cell with a PC-controlled Solartron 1250 Frequency Analyser coupled to a Solartron 1286 Electrochemical Interface using ZPlot 2.4 software. A sinusoidal voltage perturbation of $10 \mathrm{mV}$ (rms) was applied, scanning from $65 \mathrm{kHz}$ to $0.1 \mathrm{~Hz}$ with 10 points per frequency decade and an integration time of $120 \mathrm{~s}$.

\subsection{Prussian Blue deposition}

Thin Prussian Blue films were prepared by polarizing a GC electrode $(3 \mathrm{~mm}$ diameter) at $0.40 \mathrm{~V}$ in an aqueous solution containing $2.5 \times 10^{-3} \mathrm{molL}^{-1} \quad \mathrm{FeCl}_{3}+2.5 \times 10^{-3} \mathrm{~mol} \mathrm{~L}^{-1}$ $\mathrm{K}_{3} \mathrm{Fe}(\mathrm{CN})_{6}+0.10 \mathrm{~mol} \mathrm{~L}^{-1} \mathrm{KCl}+0.10 \mathrm{~mol} \mathrm{~L}^{-1} \mathrm{HCl}$. After deposition, the film was activated in a $0.10 \mathrm{~mol} \mathrm{~L}^{-1}$ $\mathrm{KCl}+0.10 \mathrm{~mol} \mathrm{~L}^{-1} \mathrm{HCl}$ solution by cycling 50 times from -0.20 to $0.60 \mathrm{~V}$, at $50 \mathrm{mV} \mathrm{s}^{-1}$. In the text this electrode is referred to as $\mathrm{GC} / \mathrm{PB}$.

\subsection{Copper hexacyanoferrate deposition}

Thin $\mathrm{CuHCNFe}$ films were prepared by applying triangular potential sweeps $\left(0.05 \mathrm{~V} \mathrm{~s}^{-1}\right)$ in the potential range -0.3 to $0.9 \mathrm{~V}$ versus SCE in a solution containing $5 \times 10^{-3} \mathrm{~mol} \mathrm{~L}^{-1}$ $\mathrm{K}_{3} \mathrm{Fe}(\mathrm{CN})_{6}+5 \times 10^{-3} \mathrm{~mol} \mathrm{~L}^{-1} \mathrm{CuCl}_{2}+0.1 \mathrm{~mol} \mathrm{~L}^{-1} \mathrm{KCl}$. The $\mathrm{pH}$ of the solution was adjusted with $\mathrm{HCl}$ to 3 . In the text this electrode will be referred to as $\mathrm{GC} / \mathrm{CuHCNFe}$.

\subsection{Copper hexacyanoferrate/polypyrrole hybrid deposition}

Copper hexacyanoferrates/polypyrrole films were formed in a two-step procedure. In the first stage, a hexacyanoferrate(III)doped polypyrrole film was deposited onto the electrode by applying triangular potential sweeps (at scan rate $0.05 \mathrm{~V} \mathrm{~s}^{-1}$ ) in the potential range -0.3 to $0.9 \mathrm{~V}$ versus SCE in solutions containing $2 \times 10^{-2} \mathrm{~mol} \mathrm{~L}^{-1} \mathrm{~K}_{3} \mathrm{Fe}(\mathrm{CN})_{6}+0.1 \mathrm{~mol} \mathrm{~L}^{-1}$ $\mathrm{KCl}+1.5 \times 10^{-2} \mathrm{~mol} \mathrm{~L}^{-1}$ pyrrole. The second step consisted in placing the $\mathrm{Fe}(\mathrm{CN}) 6^{3-} / \mathrm{PPy}$ modified electrode in a solution containing $2 \times 10^{-2} \mathrm{~mol} \mathrm{~L}^{-1} \mathrm{CuCl}_{2}+0.1 \mathrm{~mol} \mathrm{~L}^{-1} \mathrm{KCl}$ during $2 \mathrm{~h}$. After that, the electrode was cycled 20 times in the same electrolyte, transferred to a solution containing $0.1 \mathrm{~mol} \mathrm{~L}^{-1} \mathrm{KCl}$ and cycled until stabilisation of the peaks corresponding to copper hexacyanoferrate oxidation/reduction. In the text this electrode will be referred to as GC/CuHCNFe/PPy.

\subsection{Enzyme immobilization}

Glucose oxidase (GOx) was immobilised onto the electrode surface by the cross-linking method, using a mixture of glutaraldehyde (GA), enzyme and BSA. To prepare $30 \mu \mathrm{L}$ of this mixture, $10 \mu \mathrm{L}$ of glutaraldehyde $(2.5 \% \mathrm{v} / \mathrm{v}$ diluted in water $)$ were added to $25 \mu \mathrm{L}$ of enzyme solution. The enzyme solution was prepared by dissolving $40 \mathrm{mg}$ of BSA and $10 \mathrm{mg}$ of GOx in $1 \mathrm{~mL}$ of $0.1 \mathrm{~mol} \mathrm{~L}^{-1}$ phosphate buffer solution, $\mathrm{pH} 7$. From this mixture, $10 \mu \mathrm{L}$ were placed onto the surface of the working electrode and allowed to dry at room temperature.

\subsection{Amperometric measurements}

The amperometric response of modified electrodes to $\mathrm{H}_{2} \mathrm{O}_{2}$ additions was carried out in a conventional three-electrode electrochemical cell $(5 \mathrm{~mL})$ containing stirred electrolytes. Before successive $\mathrm{H}_{2} \mathrm{O}_{2}$ additions, the electrodes were held at the operating potential until the background current stabilised.

Tests of the biosensor response to glucose were made in a three-electrode electrochemical cell $(5 \mathrm{~mL})$ containing stirred sodium phosphate buffer solution $\left(0.10 \mathrm{~mol} \mathrm{~L}^{-1}, \mathrm{pH} 7.0\right)$ as electrolyte.

\section{Results and discussion}

\subsection{Electrochemical synthesis}

The hexacyanoferrate/pyrrole matrix was prepared by potential cycling in an aqueous solution containing $2 \times 10^{-2} \mathrm{~mol} \mathrm{~L}^{-1}$ $\mathrm{K}_{3} \mathrm{Fe}(\mathrm{CN})_{6}+0.1 \mathrm{~mol} \mathrm{~L}^{-1} \mathrm{KCl}+1.5 \times 10^{-2} \mathrm{~mol} \mathrm{~L}^{-1}$ pyrrole. Fig. 1a shows the voltammograms recorded with a $3 \mathrm{~mm}$ diameter glassy carbon electrode immersed in this solution. A first broad peak at $0.3 \mathrm{~V}$ corresponding to ferrocyanide oxidation and a second wave starting at $0.7 \mathrm{~V}$, attributed to oxidation of the pyrrole monomer, can be observed. The electrode was cycled 10 times in the potential range -0.3 to $0.9 \mathrm{~V}$. The positive potential limit chosen was lower than $1.0 \mathrm{~V}$ in order to avoid overoxidation of the polymer, which leads to loss of its conductivity $[20,21]$. As can be seen in Fig. 1a, during cycling an increase in the current in the region of $0.1 \mathrm{~V}$ occurs, corresponding to oxidation/reduction of the polypyrrole formed during the process, demonstrating the growth of the conducting polymer. After the deposition process, a homogeneous blue film can be observed on the electrode, with good mechanical stability. 


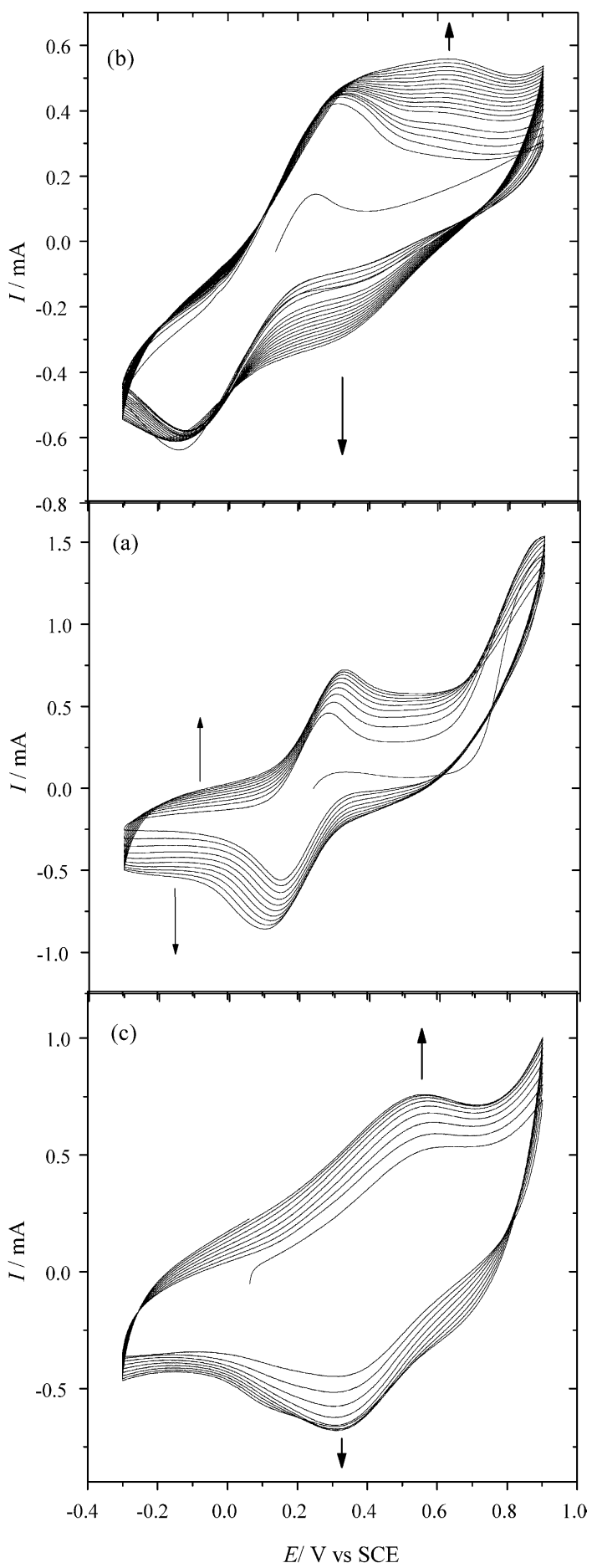

Fig. 1. (a) Electrosynthesis of $\mathrm{Fe}(\mathrm{CN})_{6}{ }^{-4}$ doped polypyrrole. Electrolyte: $\mathrm{K}_{3} \mathrm{Fe}(\mathrm{CN})_{6} \quad 2 \times 10^{-2} \mathrm{~mol} \mathrm{~L}^{-1}+$ pyrrole $1.5 \times 10^{-2} \mathrm{~mol} \mathrm{~L}^{-1}+\mathrm{KCl}$ $0.1 \mathrm{~mol} \mathrm{~L}^{-1} ; \quad v=50 \mathrm{mV} \mathrm{s}^{-1} ; 10$ cycles. (b) Cyclic voltammograms of $\mathrm{Fe}(\mathrm{CN})_{6}{ }^{4-}$ doped polypyrrole in $\mathrm{CuCl}_{2} 2 \times 10^{-3} \mathrm{~mol} \mathrm{~L}^{-1}+\mathrm{KCl} 0.1 \mathrm{~mol} \mathrm{~L}^{-1}$. $v=50 \mathrm{mV} \mathrm{s}^{-1} ; 20$ cycles. (c) Cyclic voltammograms of $\mathrm{Fe}(\mathrm{CN})_{6}{ }^{4-}$ doped $\mathrm{KCl}$ $0.1 \mathrm{~mol} \mathrm{~L}^{-1} \cdot v=50 \mathrm{mV} \mathrm{s}^{-1} ; 20$ cycles.

Next, the $\mathrm{Fe}(\mathrm{CN}) 6^{3-} / \mathrm{PPy}$ modified electrode was placed in a solution containing $2 \times 10^{-2} \mathrm{~mol} \mathrm{~L}^{-1} \mathrm{CuCl}_{2}+0.1 \mathrm{~mol} \mathrm{~L}^{-1} \mathrm{KCl}$ during $2 \mathrm{~h}$, in order to allow the insertion of $\mathrm{Cu}^{2+}$ ions into the polymer network. After this process, it is supposed that both $\mathrm{Fe}(\mathrm{CN})_{6}{ }^{3-}$ and $\mathrm{Cu}^{2+}$ ions are present inside the polymer matrix.
The electrode was then cycled 20 times in the same electrolyte. Results are shown in Fig. 1b, where the appearance and growth of a new oxidation peak at $0.7 \mathrm{~V}$ and its complementary reduction peak at $0.4 \mathrm{~V}$ are seen. This redox couple corresponds to the oxidation/reduction of copper hexacyanoferrate [22] and the increase of current with the number of cycles indicates growth of the copper hexacyanoferrate inside the polymeric matrix.

When the electrode is transferred to an aqueous electrolyte containing only $0.1 \mathrm{~mol} \mathrm{~L}^{-1} \mathrm{KCl}$ and cycled between -0.3 and $0.9 \mathrm{~V}$, the peaks corresponding to oxidation/reduction of the copper hexacyanoferrate still increase, as illustrated in Fig. 1c. For this reason, the electrode was cycled until complete stabilisation of these peaks. All these results give strong evidence for the incorporation of copper hexacyanoferrate into the polymer network.

\subsection{Electrocatalytic properties of the hybrid film}

When held at a constant potential of $0.0 \mathrm{~V}$, the GC/CuHCNFe/PPy electrode shows a cathodic current response to added hydrogen peroxide. Fig. 2a depicts the response to peroxide, added in portions of $0.025 \mathrm{mmol} \mathrm{L}^{-1}$. As shown in Fig. 2b, the dependence of the catalytic current on the concentration of hydrogen peroxide was linear and reproducible up to $0.5 \mathrm{mmol} \mathrm{L}^{-1}$ of peroxide, with a sensitivity of $726 \mu \mathrm{Ammol}^{-1} \mathrm{~L} \mathrm{~cm}^{-2}$ and a detection limit (three times the standard deviation of the slope) of $13 \mu \mathrm{mol} \mathrm{L}^{-1}$.

For comparison, peroxide detection tests were performed with both copper hexacyanoferrate and Prussian Blue modified glassy carbon electrodes, as described in Section 2. The sensitivities (summarised in Table 1) obtained were 0.14 and $340 \mu \mathrm{Ammol}^{-1} \mathrm{~L} \mathrm{~cm}^{-2}$, respectively. The copper hexacyanoferrate/polypyrrole hybrid exhibits a sensitivity of $726 \mu \mathrm{A} \mathrm{mmol}^{-1} \mathrm{~L} \mathrm{~cm}^{-2}, 5000$ times higher than the copper hexacyanoferrate alone and, surprisingly, two times higher than the Prussian Blue modified electrode. This result is very striking due to the fact that it is well known from the literature that Prussian Blue analogues normally exhibit lower sensitivities for hydrogen peroxide detection than Prussian Blue itself [7,23]. This improvement can be related to the electronic conductivity of polypyrrole.

In the same way, in previous work [19], the high catalytic activity of a nickel hexacyanoferrate/polypyrrole hybrid was reported. When compared to nickel hexacyanoferrate alone, this hybrid material was found to be much more active to $\mathrm{H}_{2} \mathrm{O}_{2}$

Table 1

Sensitivities for $\mathrm{H}_{2} \mathrm{O}_{2}$ detection at $0.0 \mathrm{~V}$ vs. SCE in $0.1 \mathrm{~mol} \mathrm{~L}^{-1} \mathrm{KCl}$ for the different compounds studied

\begin{tabular}{lc}
\hline Compound & Sensitivity $\left(\mu \mathrm{Ammol}^{-1} \mathrm{Lcm}^{-2}\right)$ \\
\hline CuHCNFe & 0.14 \\
CuHCNFe/PPy & 726.00 \\
Prussian Blue & 340.00 \\
NiHCNFe & 9.61 \\
NiHCNFe/PPy [19] & 88.30 \\
\hline
\end{tabular}



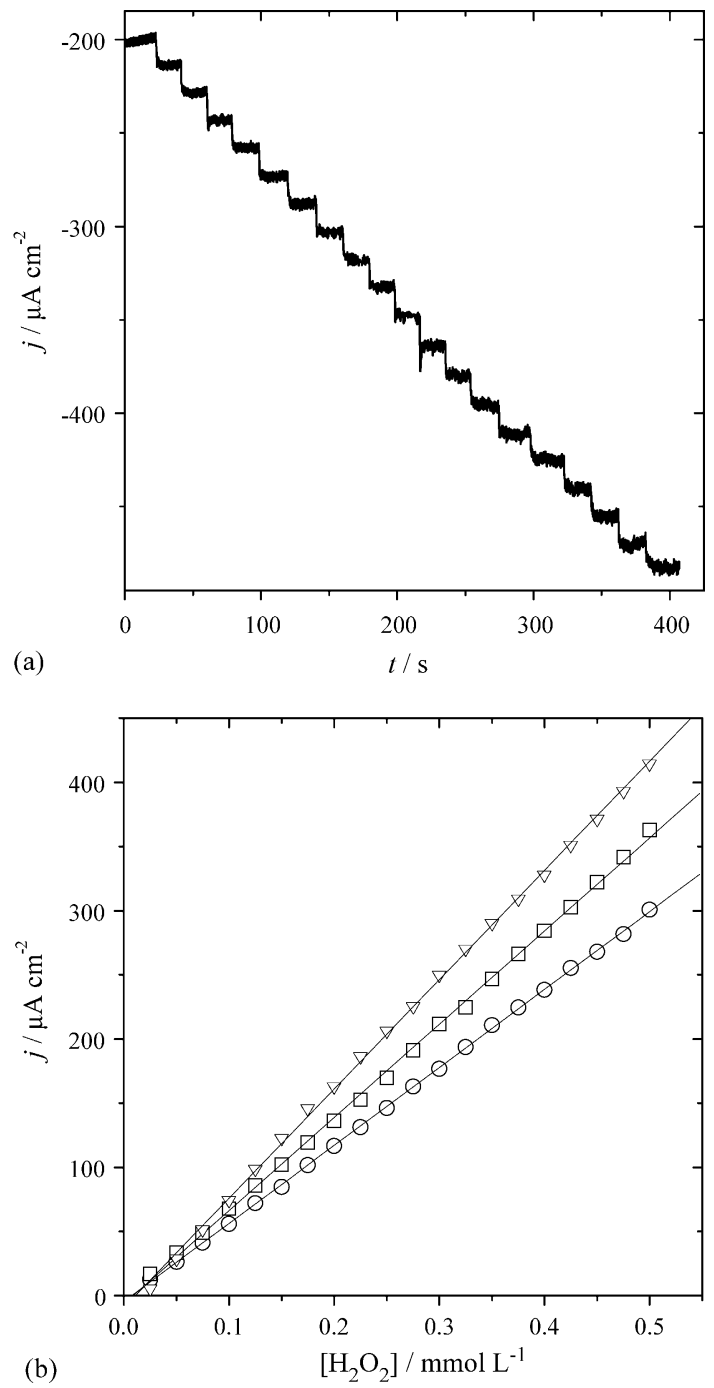

Fig. 2. (a) Typical amperometric response during the determination of $\mathrm{H}_{2} \mathrm{O}_{2}$ with a PPy/CuHCNFe hybrid glassy carbon modified electrode at $0.0 \mathrm{~V}$ vs. SCE. (b) Analytical curves obtained for $\mathrm{H}_{2} \mathrm{O}_{2}$ determination at $0.0 \mathrm{~V}$ vs. SCE in $0.1 \mathrm{~mol} \mathrm{~L}^{-1} \mathrm{KCl}+0.1 \mathrm{~mol} \mathrm{~L}^{-1} \mathrm{HCl}$ with a PPy/CuHCNFe hybrid glassy carbon modified electrode.

because of the higher electronic conductivity of the hybrid owing to the presence of the conducting polymer matrix. As can be seen in Table 1, even though nickel hexacyanoferrate has a higher activity than the copper analogue, the improvement of the sensitivity provoked by the presence of polypyrrole in $\mathrm{GC} / \mathrm{CuHCNFe} / \mathrm{PPy}$ hybrid electrode is much more drastic than in the case of the hybrid material containing nickel hexacyanoferrate. This fact is an evidence of the relevant role played by the conducting polymer matrix in the enhancement of the catalytic properties of this hybrid material. The high catalytic performance of the hybrid containing copper must be related to the synthetic approach used to prepare the modified electrode due to the fact that the nickel containing hybrid is prepared in a simple one step method. The two-step procedure used to synthesize the copper hybrid seems to be much more efficient for the incorporation of copper hexacyanoferrate that would be in intimate contact with the conducting polymer chains.

\subsection{Electrochemical impedance spectroscopy}

With the aim of characterizing the electronic and transport properties of $\mathrm{CuHCNFe/PPy} \mathrm{hybrid} \mathrm{films,} \mathrm{electrochemi-}$ cal impedance experiments were performed. These experiments were performed at $0.0 \mathrm{~V}$ because this is the potential used in the $\mathrm{H}_{2} \mathrm{O}_{2}$ detection experiments. Fig. 3 shows complex plane spectra for $\mathrm{CuHCNFe/PPy} \mathrm{and} \mathrm{CuHCNFe} \mathrm{films.} \mathrm{As} \mathrm{can} \mathrm{be} \mathrm{seen,}$ the presence of the conducting polymer dramatically modifies the impedance response of the system. In the case of hybrid material, a semicircle is clearly observed at high frequencies, the diameter of this semicircle being related to the resistance of the charge transfer reaction and the electronic resistance of the film. By analyzing the low frequency region, it is possible to observe a transition from semi-infinite diffusion, where the curve has a phase angle of $45^{\circ}$, to a finite diffusion process with the angle approaching $90^{\circ}$; this impedance diagram shows the typical shape expected for a thin conducting polymer film [24].
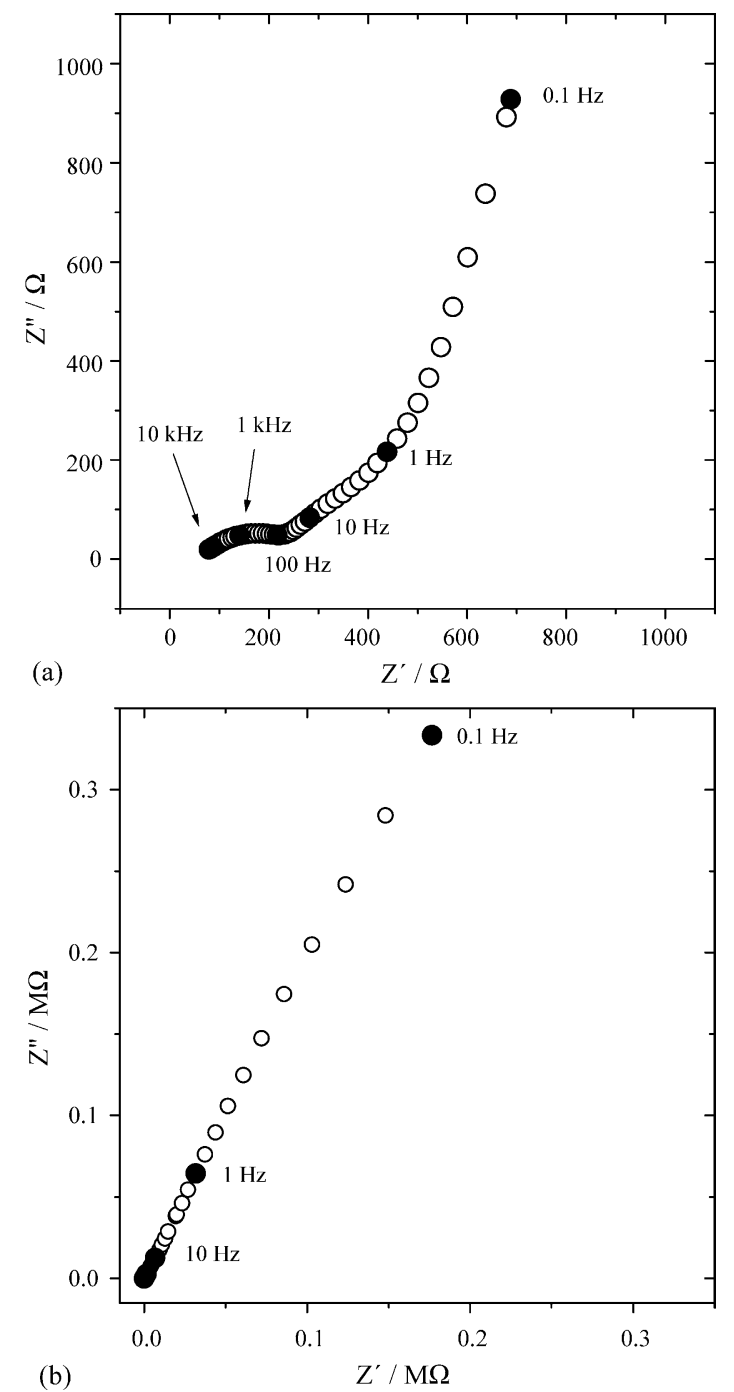

Fig. 3. (a) Electrochemical impedance diagrams (Nyquist plot) of CuHC$\mathrm{NFe} / \mathrm{PPy}$ hybrid and (b) of NiHCNFe films. at $0.0 \mathrm{~V}$. Frequency range: $100 \mathrm{kHz}-0.01 \mathrm{~Hz}$. Amplitude $(\mathrm{rms})=5 \mathrm{mV}$. Electrolyte solution: $0.1 \mathrm{~mol} \mathrm{~L}^{-1}$ $\mathrm{KCl}, \mathrm{pH} 3$. 
On the other hand, the impedance diagram of the CuHCNFe film shows a higher value of the film resistance $(\sim 20 \mathrm{k} \Omega$ versus $\sim 20 \Omega$ ) in the high frequency region whereas, from the low frequency region, we can conclude that the ionic movement inside the $\mathrm{CuHCNFe}$ film is slower than inside the hybrid one. An infinite diffusion process is observed in the same frequency range where the hybrid film exhibits a finite diffusion process. In other words, the presence of the conducting polymer improves both electronic and ionic conductivities of the film.

As mentioned above, the hybrid shows a better performance for the determination of $\mathrm{H}_{2} \mathrm{O}_{2}$ than CuHCNFe itself; this improvement being related to the increased electronic conductivity in the hybrid due to the polypyrrole network. The conducting polymer can act as a "wire", connecting the redox sites of $\mathrm{CuHCNFe}$, thus increasing the charge transfer rate. This can be confirmed by performing a simple experiment overoxidizing the polypyrrole matrix to reduce the polymer conductivity and evaluating the influence of the drop in conductivity on the analytical performance of $\mathrm{H}_{2} \mathrm{O}_{2}$ detection. The overoxidation process is characterized by an irreversible nucleophilic attack when the polymer is exposed to high positive potentials in aqueous solutions, with the subsequent loss of electroactivity and electronic conductivity [25]. First, the polypyrrole was partially oxidized by applying a potential of $1.0 \mathrm{~V}$ in $0.1 \mathrm{~mol} \mathrm{~L}^{-1} \mathrm{KCl}$ : Fig. 4 a shows the impedance diagram after this process where an increase in the diameter of the high frequency semicircle can be observed, indicating that the resistivity of the film is higher and, consequently, also the charge transfer resistance. After that, the electrode was used to determine $\mathrm{H}_{2} \mathrm{O}_{2}$ in the same conditions as those used in Fig. 2. The resulting analytical curve is inserted in the figure and a sensitivity value of $295 \mu \mathrm{A} \mathrm{mmol}^{-1} \mathrm{~L} \mathrm{~cm}^{-2}$ was obtained, demonstrating that the decrease in polypyrrole conductivity is reflected in a sensitivity loss towards $\mathrm{H}_{2} \mathrm{O}_{2}$ detection.

The electrode was then cycled between -0.3 and $1.2 \mathrm{~V}$ in aqueous $0.1 \mathrm{mmol} \mathrm{L}^{-1} \mathrm{KCl}$ electrolyte, in order to cause full overoxidation of the polypyrrole and total loss of polymer electroactivity. The complex plane impedance plot obtained after this process is shown in Fig. 4b. A drastic increase in the impedance values to the order of $\mathrm{M} \Omega$ can be observed, showing the complete loss of electronic conductivity of polypyrrole. After this treatment, the electrode was almost unable to detect $\mathrm{H}_{2} \mathrm{O}_{2}$, responding to successive additions of $\mathrm{H}_{2} \mathrm{O}_{2}$ only when the increase in the concentration was made as high as $0.25 \mathrm{mmol} \mathrm{L}^{-1}$ per addition. Thus, it can be concluded that the influence of the electronic conductivity of the polypyrrole in the analytical performance of the hybrid in $\mathrm{H}_{2} \mathrm{O}_{2}$ determination is crucial.

\subsection{Biosensors based on the PPy/CuHCNFe hybrid}

The hybrid film was used for constructing a biosensor for the determination of glucose by immobilizing the enzyme glucose oxidase onto a hybrid modified glassy carbon electrode. Fig. 5a illustrates a typical current-time plot for a GC/CuHCNFe/PPy/GOx electrode that was obtained by injecting successive aliquots of stock glucose solution. The measurements were performed at $0.0 \mathrm{~V}$, by injection
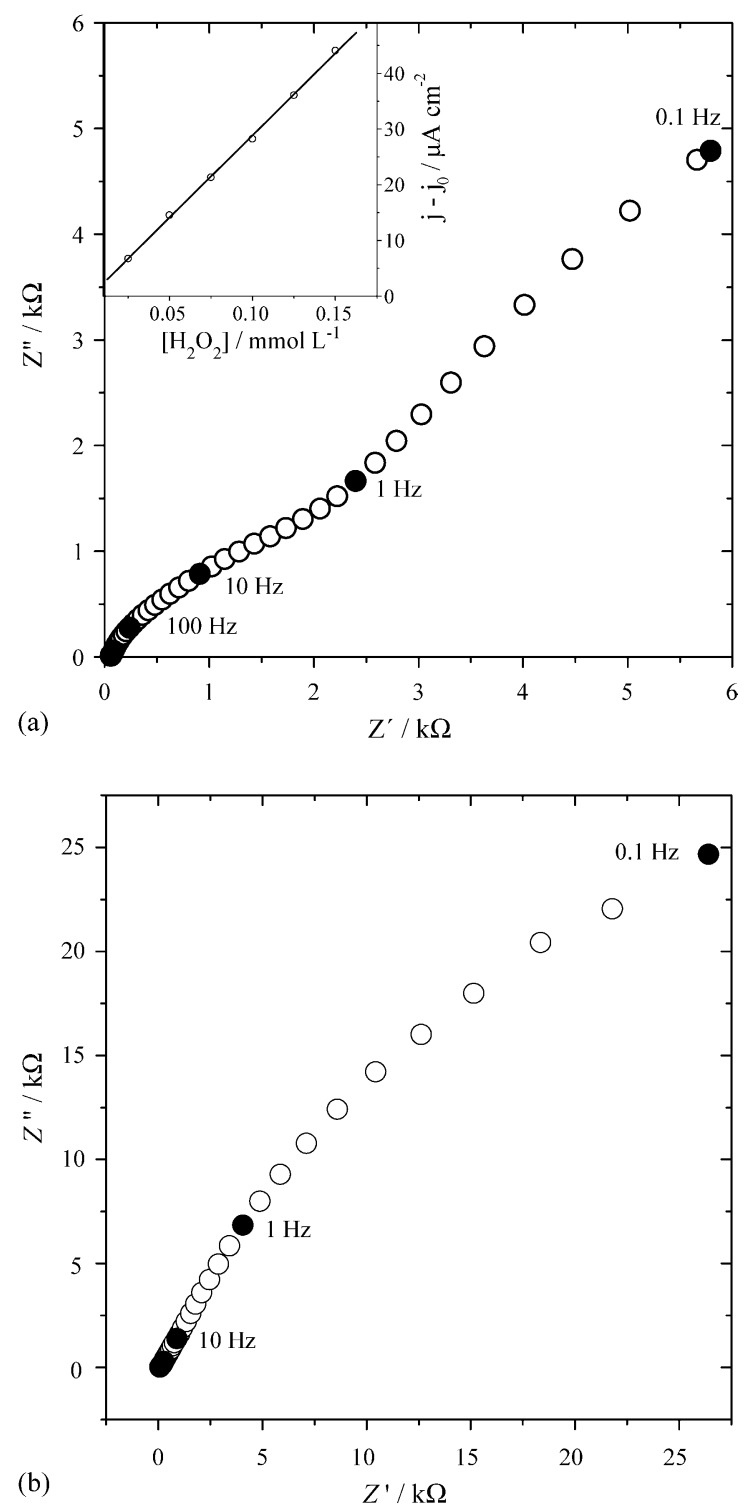

Fig. 4. Complex plane impedance spectra at $0.0 \mathrm{~V}$ vs. SCE of (a) a $\mathrm{GC} / \mathrm{CuHCNFe} / \mathrm{PPy}$ electrode after being partially overoxidised. The insert corresponds to the analytical curve obtained with the hybrid electrode after the partial overoxidation of the polypyrrole. (b) A GC/CuHCNFe/PPy electrode after being totally overoxidised till $1.0 \mathrm{~V}$

of $10 \mu \mathrm{L}$ of $0.2 \mathrm{~mol} \mathrm{~L}^{-1}$ glucose solution into $20 \mathrm{~mL}$ of $0.1 \mathrm{~mol} \mathrm{~L}^{-1} \mathrm{PBS}+0.05 \mathrm{~mol} \mathrm{~L}^{-1} \mathrm{NaCl}$ solution under continuous stirring. Fig. 5b displays the analytical curve, where the linear range extends from 0.02 to $1.0 \mathrm{mmol} \mathrm{L}^{-1}$, the sensitivity obtained being $34.9 \mu \mathrm{A} \mathrm{mmol}^{-1} \mathrm{~L} \mathrm{~cm}^{-2}$ and the detection limit $5.4 \mu \mathrm{mol} \mathrm{L}-1$.

It should be stressed that the biosensor is working in $\mathrm{Na}^{+}$containing buffer and even so, the sensitivity is 2.1 times higher than that reported for a glucose sensor based on layerby-layer deposition of GOx onto Prussian Blue ITO-modified electrodes [26] in $\mathrm{K}^{+}$electrolytes. Consequently, the CuHCNFe hybrid composite not only overcomes Prussian Blue's limitation for working in $\mathrm{Na}^{+}$containing solutions but also leads to a better sensitivity. Other glucose biosensors reported 


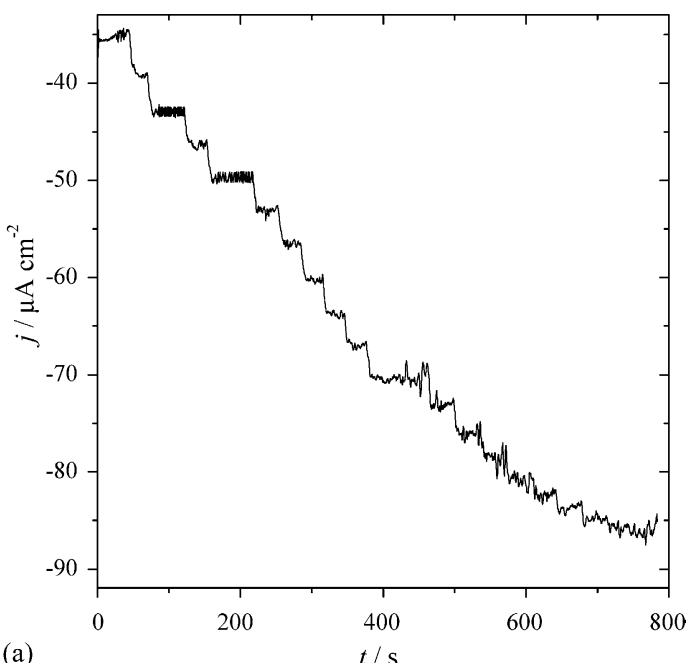

(a)

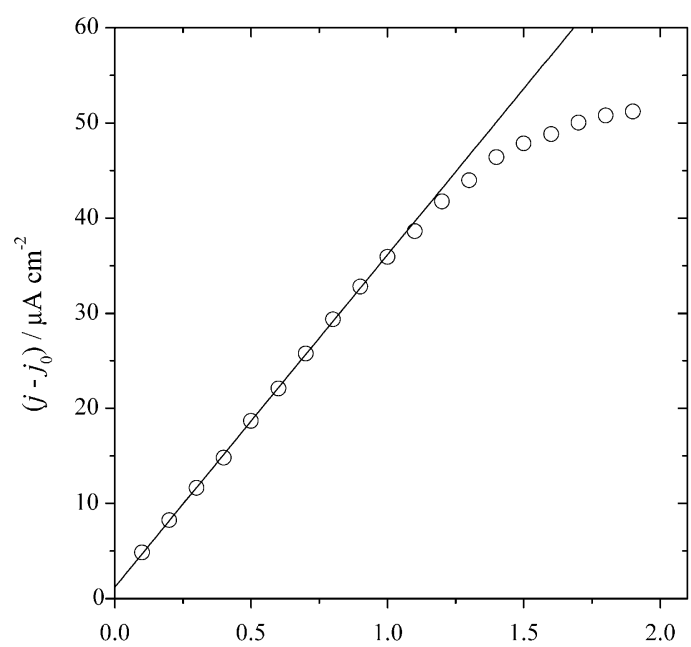

(b)

[glucose] $/ \mathrm{mmol} \mathrm{L}^{-1}$

Fig. 5. (a) Typical amperometric response during glucose biosensing with a PPy/CuHCNFe/GOD glassy carbon modified electrode. (b) Analytical curves obtained for glucose determination at $0.00 \mathrm{~V}$ vs. SCE in $0.1 \mathrm{~mol} \mathrm{~L}^{-1}$ $\mathrm{PBS}+0.05 \mathrm{~mol} \mathrm{~L}^{-1} \mathrm{NaCl}(\mathrm{pH}$ 7) with a PPy/CuHCNFeGOD glassy carbon modified electrode.

in the literature can be compared and it can be confirmed that the performance of the $\mathrm{GC} / \mathrm{CuHCNFe} / \mathrm{PPy} / \mathrm{GOx}$ electrode is better than that obtained for other electrodes such as GOx co-immobilized with ferrocene from ethanol/water mixtures [27] $\left(1.5 \mu \mathrm{A} \mathrm{mmol}^{-1} \mathrm{~L} \mathrm{~cm}^{-2}\right)$, GOx immobilized in an osmium-based three-dimensional redox hydrogel [28] (5.2 $\mu \mathrm{A} \mathrm{mmol}^{-1} \mathrm{~L} \mathrm{~cm}^{-2}$ ), GOx trapped inside an electropolymerised film [29] $\left(0.28 \mu \mathrm{A} \mathrm{mmol}^{-1} \mathrm{~L} \mathrm{~cm}^{-2}\right)$, GOx immobilized onto carbon film electrodes [30] $\left(0.25 \mu \mathrm{A} \mathrm{mmol}^{-1} \mathrm{~L} \mathrm{~cm}^{-2}\right)$ or $4.0 \mu \mathrm{A} \mathrm{mmol}^{-1} \mathrm{~L} \mathrm{~cm}^{-2}$ for GOx within a polypyrrole film electrogenerated onto mesoporous $\mathrm{TiO}_{2}[31]$.

\section{Conclusions}

The synthesis of a new organic/inorganic hybrid material was performed by combining polypyrrole and a hexacyanometalate (CuHCNFe), aiming to obtain an electrocatalyst for $\mathrm{H}_{2} \mathrm{O}_{2}$ reduc- tion in the presence of either $\mathrm{Na}^{+}$or $\mathrm{K}^{+}$ions. The use of this material as a redox mediator in a glucose biosensor based on the immobilisation of glucose oxidase enzyme was also discussed. The electrochemical properties of the hybrid material were investigated and compared with those of the copper hexacyanoferrate film by itself. The electrocatalytic properties of the hybrid are better than those of the CuHCNFe film due to the presence of polypyrrole chains that enhance the electronic conductivity of the material.

\section{Acknowledgements}

Brazilian agencies FAPESP (Procs. 03/07568-0 and 03/10015-3) and CNPq-CTEnerg (Proc. 400562/2003-0) are gratefully acknowledged for financial support. P.A.F. thanks FAPESP (Proc. 01/04957-2) and Alfa ADEMAT network (EU) for fellowships granted. C.B. thanks ICEMS.

\section{References}

[1] R. Pauliukaite, M. Florescu, C.M.A. Brett, J. Solid State Electrochem. 9 (2005) 254.

[2] R. Konski, Crit. Ver. Anal. Chem. 32 (2002) 79.

[3] A.A. Karyakin, Electroanalysis 13 (2001) 813.

[4] A.A. Karyakin, O.V. Gitelmacher, E.E. Kariakina, Anal. Lett. 27 (1994) 2861.

[5] R. Grajonyte, A. Malinauskas, Sens. Actuators B 56 (1999) 93.

[6] J. Wang, X.J. Zhang, M. Prakash, Anal. Chim. Acta 395 (1999) 11.

[7] I.L. Mattos, L. Gorton, T. Laurell, A. Malinauskas, A.A. Karyakin, Talanta 52 (2000) 791.

[8] M.S. Lin, Y.C. Wu, B.I. Jan, Biotechnol. Bioeng. 62 (1999) 56.

[9] S.M. Chyn, J. Electroanal. Chem. 521 (2002) 29.

[10] A. Eftekhari, Microchim. Acta 141 (2003) 15.

[11] M. Florescu, C.M.A. Brett, Anal. Lett. 37 (2004) 871.

[12] C.X. Cai, K.H. Xue, Y.M. Zhou, H. Yang, Talanta 44 (1997) 339.

[13] S. Milardovic, I. Kruhak, D. Ivekovic, V. Rumenjak, M. Tkalcec, B.S. Grabaric, Anal. Chim. Acta 350 (1997) 91.

[14] I.L. Mattos, L. Gorton, Quim. Nova 24 (2001) 200.

[15] K. Backskai, K. Martinusz, E. Czirok, G. Inzelt, P.J. Kulesza, J. Electroanal. Chem. 385 (1995) 241.

[16] S. Sinha, B.D. Humphrey, A.B. Bocarsky, Inorg. Chem. 23 (1984) 202.

[17] S. Zamponi, M. Berrettoni, P.J. Kulesza, K. Liecznikowski, K. Malik, O. Makowski, R. Marassi, Electrochim. Acta 48 (2003) 4261.

[18] M.A. Malik, K. Miecznikowski, P.J. Kulesza, Electrochim. Acta 45 (2000) 3777.

[19] P.A. Fiorito, S.I. Córdoba de Torresi, J. Electroanal. Chem. 581 (2005) 31.

[20] T.V. Vernitskaya, O.N. Efimov, Russ. Chem. Rev. 66 (1997) 443.

[21] P. Gros, A. Bergel, J. Electroanal. Chem. 386 (1995) 65.

[22] S.-M. Chen, C.-M. Chan, J. Electroanal. Chem. 543 (2003) 161.

[23] R. Garjonyte, A. Malinauskas, Sens. Actuators B 56 (1999) 93.

[24] M.A. Vorotyntsev, L.I. Daikhin, M.D. Levi, J. Electroanal. Chem. 364 (1994) 37.

[25] J.B. Schlenoff, H. Xu, J. Electrochem. Soc. 139 (1992) 2397.

[26] M. Ferreira, P.A. Fiorito, O.N. Oliveira Jr., S.I. Córdoba de Torresi, Biosens. Bioelectron. 19 (2004) 1611.

[27] P.A. Fiorito, S.I. Córdoba de Torresi, J. Braz. Chem. Soc. 12 (2001) 729.

[28] T.J. Ohara, R. Rajagopalan, A. Heller, Anal. Chem. 66 (1994) 2451.

[29] J.C. Vidal, E. Garcia, J.R. Castillo, Biosens. Bioelectron. 13 (1998) 371.

[30] M.E. Ghica, C.M.A. Brett, Anal. Lett. 38 (2001) 907.

[31] S. Cosnier, A. Senillou, M. Grätzel, P. Comte, N. Vlachopoulos, N.J. Renault, C. Martelet, J. Electroanal. Chem. 469 (1990) 176. 